\title{
Die \\ Civillprozépordnang
}

für bas

\section{Dentride Reidd.}

Amtlibe Ausgabe.

Mit Sadregifter.

3weitex 2rbbrudx.

Berfin, 1878.

Drud und $\mathfrak{B}$ erlag oon (S. Reimer. 



\section{Civilurouespordment.}


